DOI: https://doi.org/10.31933/dijms.v2i6

Received: 14 July 2021, Revised: 15 August 2021, Publish: 25 August 2021

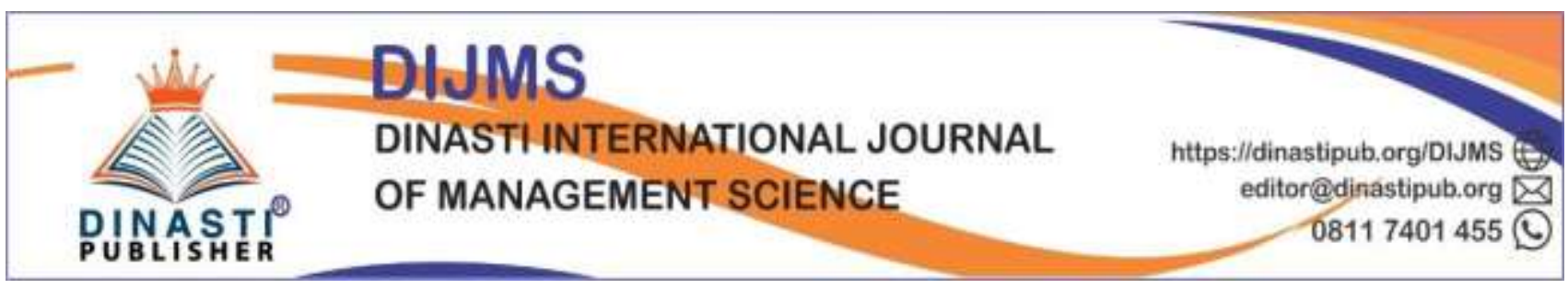

\title{
THE INFLUENCE OF ORGANIZATIONAL CULTURE, ORGANIZATIONAL COMMITMENT AND MOTIVATION ON PERFORMANCE EMPLOYEE AT PT. KPP
}

\author{
Rizkah Rizkah ${ }^{1}$, Chaerudin Chaerudin ${ }^{2}$ \\ 1) Mercu Buana University, Jakarta, Indonesia, rizkarizkah@ gmail.com \\ 2) Mercu Buana University, Jakarta, Indonesia, chaerudin@mercubuana.ac.id
}

\section{Corresponding Author: First Author}

\begin{abstract}
This study aims to analyze the influence of organizational culture, organizational commitment and motivation on performance employee at PT. KPP, with a population 77 people are all employees of PT. KPP. The sampling method used is non-probability sampling and the form of the sampling technique is the saturated sampling technique. Multiple linear regressions as the data analysis technique used. There is a significant influence between organizational culture and motivation but organizational commitment does not partially significantly affect the performance of employees of PT. KPP, finding the results of organizational culture, organizational commitment and motivation simultaneously have to effect on the performance of employees PT. KPP.
\end{abstract}

Keywords: Organizational culture, organizational commitment, motivation and employee performance.

\section{INTRODUCTION}

The rapid pace of sector development in all industries, raises competitors in the business world along with the presence of an innovative product or service that they create. The production and marketing strategies consciously encourage companies to compete to determine the best strategy. The implementation of the HRM system starting from the hiring stage to the job appraisal stage is something that an organization needs to pay attention to be ready to face these challenges, therefore an appropriate strategy in needed to maintain survival and achieve company goals, which, is followed by rapid economic growth and change on business activities.

PT. KPP is a company that has a vision as a company that continue to excel, be professional and continuously innovative in the provision of educational services. In order to achieve the company's goals, it is necessary to have a work value system in the interaction and integration of work implementation within the company.

Nowadays, Indonesia, at the beginning of 2020, is facing a major disaster on very serious health issues. The presence of the Corona-19 virus which has led to the determination of policies to work, study and prayer at home. Furthermore, conditions like this force companies to implement a 
work at home policy. It is realized that operational activities cannot stop but still as much as possible ensure that operational activities continue.

Reflecting on the natural phenomena that occur, this has an impact on the work results of employees. The phenomenon of changing the form of work in the office to being at home, for the company creates new problems because of the difficulty in controlling or observing the work of the employee. This discrepancy is the focus of problem that can reduce employee performance.

Table 1. Performance Employee of PT. KPP

\begin{tabular}{|l|l|l|l|l|l|l|l|}
\hline Criteria & \multicolumn{2}{|c|}{ Scale } & Target & 2018 & $\%$ & 2019 & $\%$ \\
\hline Excellence & $8.8-10$ & $\mathrm{~A}$ & $100 \%$ & 10 & 12.25 & 9 & 11.25 \\
\hline Above & $7.5-8.7$ & $\mathrm{~B}$ & $100 \%$ & 66 & 82.50 & 66 & 82.50 \\
\hline Meet & $6.2-7.4$ & $\mathrm{C}$ & $100 \%$ & 4 & 5.00 & 5 & 6.25 \\
\hline
\end{tabular}

The results of Table 1. show that the 2018-2019 employee performance reports did not reach the target $(82.5 \%)$. For this reason, leaders play an important role in maintaning the consistency of their employees performance in control. Furthermore, the authors conducted a pre-survey of 15 employees to find variables that had an influence, the results found that organizational culture, organizational commitment and motivation were recognized as the biggest factors in achieving employee performance at PT. KPP.

It is hoped that the company will focus more on managing the new work culture. Because the true organizational culture is able to distinguish between one employee with another employee and how to interact in completing the job (A. Badawi Saluy \& Chaerudin, 2018).

Organizational commitment is a feeling that is believed by individuals for their attitudes and behavior which indirectly identifies if they are an element of the organization. If organizational commitment reflects its identification and involvement in the organizational goals. Thus, organizational commitment is assumed to be able to improve employee performance and ultimately provide an increase in company productivity, so that company goals are achieved to obtain optimal profits (Rahmat \& Farida, 2020).

In an effect to improve employee performance, it is necessary to motivate all employees in the organization. Motivation is an encouragement that is born from a person's personality in accordance with his wishes and needs for his work continuously to achieve organizational goals.

\section{LITERATURE REVIEW \\ Employee Performance}

Performance is defined as ability, performance by carrying out the mission of achieving a target that must be possessed by employee (Simamora, 2015). Performance can also refer to benchmarks against the achievement of employee tasks for a job that is charged within the organization. Performance or performance as a manisfestation of work, namely the value of the ratio between the actual work results to be specified size (Dessler, 2015).

\section{Organizational culture}

Robbins and Judge (2013), stated that organizational culture is an order that is interpreted and believed by all members of the organization so that there are differences with other organizations. The meaning of this shared order when viewed more deeply is a set of characteristics or main characteristics that are upheld in the organization. Meanwhile, in the opinion of Wibowo (2016), organizational culture is the philosophy or basic foundation adopted by the organization including 
beliefs, customs and principles that are the core of the characteristics of how to work within the organization.

\section{Organizational commitment}

Organizational commitment is like behavior that has a wide variety of meanings and measures. Organizational commitment is often defined as (1) having the confidence and strength to be serious as a member of the organization, (2) having a strong determination to achieve the organization's wishes, (3) having a certain belief in organizational goals (Luthans, 2015). Another view according to Colquitt, LePine and Wesson (2015), is the determination of workers to be serious as members of the organization.

\section{Motivation}

Human personality is influenced by motivation, so motivations is defined as a driving force that makes individuals active to lower and increase their own impulses, so they can carry out their actions according to special rules to bring then to the optimal target. The view of Hamzah B. Uno (2012), that work motivation is the embodiment of one of the elements that participate in determining a person's performance, the level of which depends on the intensity of the motivation given. Motivation is interpreted as the energy possessed by someone who directed and continuously achieves a company goal (Stephen P. Robbins and Marry Coulter, 2016).

\section{Conceptual framework}

Below is an illustration of the conceptual framework of the research.

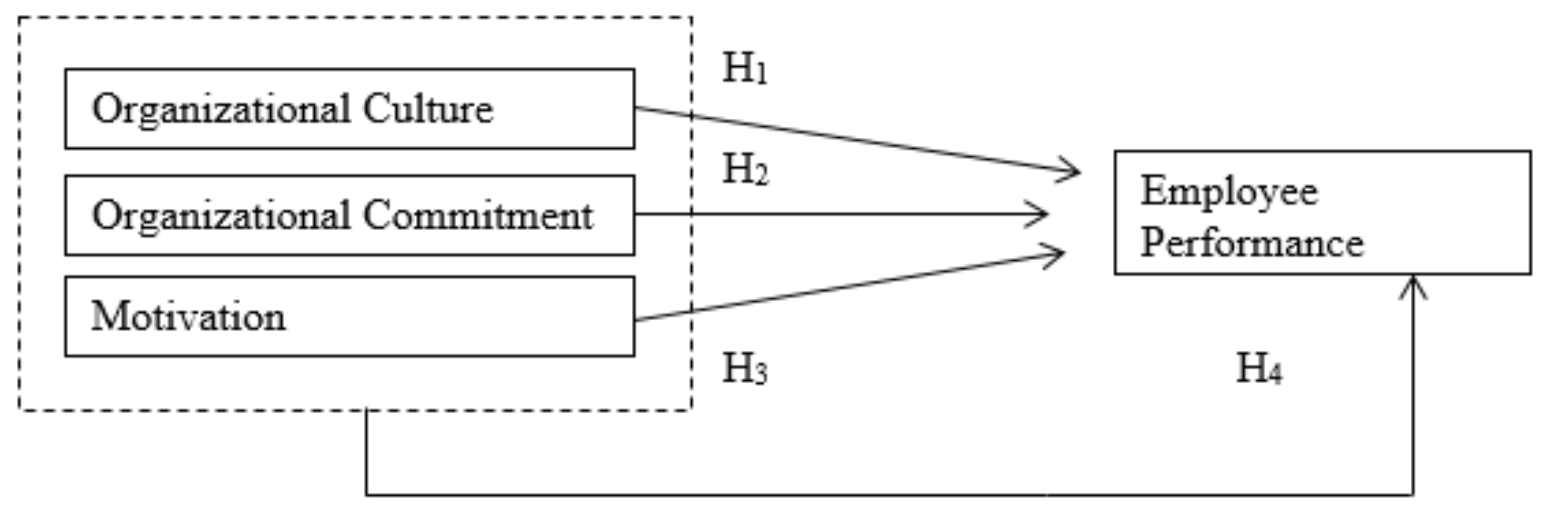

Fig. 1 Conceptual framework

\section{Hypothesis}

The formulation of the hypothesis is as follows:

- Organizational culture affects employee performance.

- Organizational commitment affects employee performance.

- Motivation has an effect on employee performance.

- Organizational culture, organizational commitment and motivation affect employee performance. 


\section{RESEARCH METHODS}

The presentation of variables in this study is the independent variable and the dependent variable. Organizational culture, organizational commitment and motivation are recognized as independent variables and employee performance as the dependent variable. All employees of PT. $\mathrm{KPP}$ as many as 77 people became respondents as well as the population in this study. The sampling method used is non-probability sampling and the form of the sampling technique is saturated sampling technique. Multiple linear regression as a data analysis technique used with SPSS 25.

\section{RESULTS AND DISCUSSION Characteristics of Respondents}

All employess pf PT. KPP a number of 77 respondents who became the sample. The scope of the characteristics seen are: gender, age, period of service, education level and status of employee in the company. Based on the results of the study, it was found that the employees of PT. KPP is occupied by female employees $(75,3 \%)$ compared to males $(24,7 \%)$. Then based on demographics on age, the results show that $(58,4 \%)$ are occupied by respondents aged $<30$ years. Furthermore, on the background of years of services obtained $(36,4 \%)$ with a working period of 2-5 years. The results of the study with educational background strata 1 and the last on the background of employee status the results of the study were dominated by permanent employees at $27,3 \%$.

From the description of the characteristics of the respondents above, most the employee of PT. KPP is filled by human resources who are productive and have qualified maturity in building an innovative and superior work system.

\section{Reability and Validity Test}

Table 2. Varible Reability Test

\begin{tabular}{llrl}
\hline Variable & Cronbach Alpha & Reliable Limit & Remarks \\
\hline X1 & 0.914 & 0.7 & Reliable \\
\hline X2 & 0.794 & 0.7 & Reliable \\
\hline X3 & 0.765 & 0.7 & Reliable \\
\hline Y & 0.859 & 0.7 & Reliable \\
\hline
\end{tabular}

From the presentation of Table 1. above, the results of the variables $\mathrm{X}$ and $\mathrm{Y}$ are concluded to be reliable, where the value of Cronbach Alpha is higher than the reliable limit of 0.7

Table 3. Variable Validity Test

\begin{tabular}{llll}
\hline Variable & Indicator & r-count & Remarks \\
& & & Valid \\
\hline $\mathrm{X} 1$ & $\mathrm{X} 1.1-\mathrm{X} 1.21$ & $0.258-0.857$ & Valid \\
\hline $\mathrm{X} 2$ & $\mathrm{X} 2.1-\mathrm{X} 2.6$ & $0.436-0.818$ & Valid \\
\hline $\mathrm{X} 3$ & $\mathrm{X} 3.1-\mathrm{X} 3.10$ & $0.464-0.697$ & Valid \\
\hline $\mathrm{Y}$ & $\mathrm{Y} 1.1-\mathrm{Y} 1.18$ & $0.265-0.794$ & \\
\hline
\end{tabular}

Based on indicator analysis, all variables are valid because of r-count higher than 0.2242.

\section{Classic assumption test}

The normality test in Table 4. below concludes that the results of the normality test show the distributin of residuals, this can be seen from the unit value of Sig, higher than 0.05 (Asymp.Sig. 0.200). 
Table 4. Normality Test

One-Sample Kolmogorov-Smirnov Test

\begin{tabular}{llr}
\hline $\mathrm{N}$ & & Unstandardized Residual \\
\hline Normal Parameters, & & 77 \\
\hline Most Extreme Differences & Mean & .0000000 \\
& Std. Deviation & 4.32836603 \\
\hline Test Statistic & Absolute & .067 \\
\hline Asymp. Sig. (2-tailed) & Positive & .067 \\
\cline { 2 - 3 } & Negative & -.049 \\
\hline
\end{tabular}

Table 5. Multicollinearity Test

\begin{tabular}{llll}
\hline & \multirow{2}{*}{ Model } & \multicolumn{3}{c}{ Collinearity Statistics } \\
\cline { 2 - 3 } & \multicolumn{3}{c}{ Tolerance } \\
\hline (Constant) & 0.763 & VIF \\
X1 & 0.652 & 1.311 \\
\hline X2 & 0.537 & 1.533 \\
\hline X3 & & 1.864 \\
\hline
\end{tabular}

The results of the multicollinearity test show that all variables have tolerance values higher than 0.10 with the VIF values lower than 10, so that multicollinearity does not occur in each of the independent variables.

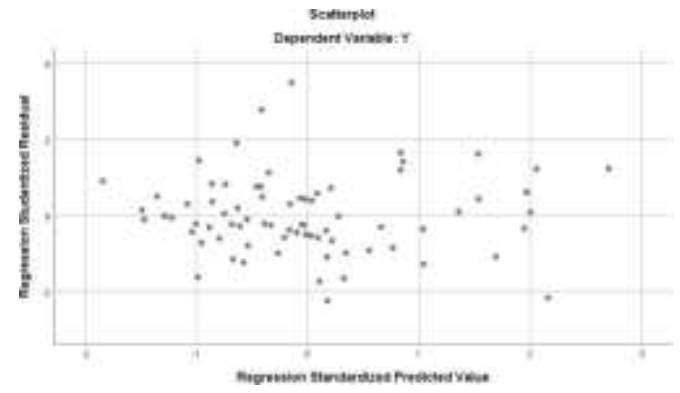

Fig. 2 Heteroscedasticity Test

Heteroscedasticity test shown Fig. 2 above the point of the irregular scattering pattern around the number 0 , so there is no heteroscedasticity characteristic. 


\section{Multiple Linear Regression Analysis Test}

Table 6. Multiple Linear Regression Test

\begin{tabular}{|c|c|c|c|c|c|}
\hline \multirow[b]{2}{*}{ Model } & \multicolumn{2}{|c|}{$\begin{array}{l}\text { Unstandardized } \\
\text { Coefficients }\end{array}$} & \multirow{2}{*}{$\begin{array}{c}\begin{array}{l}\text { Standardized } \\
\text { Coefficients }\end{array} \\
\text { Beta }\end{array}$} & \multirow[b]{2}{*}{$\mathbf{t}$} & \multirow[b]{2}{*}{ Sig. } \\
\hline & $\mathbf{B}$ & Std. Error & & & \\
\hline (Constant) & 33.289 & 6.569 & & 5.068 & 0.000 \\
\hline $\mathrm{X} 1$ & 0.209 & 0.069 & 0.324 & 3.013 & 0.004 \\
\hline $\mathrm{X} 2$ & -0.235 & 0.171 & -0.160 & 1.378 & 0.172 \\
\hline $\mathrm{X} 3$ & 0.671 & 0.193 & 0.444 & 3.467 & 0.001 \\
\hline
\end{tabular}

Based on the results of data anaysis conducted using SPSS version 25, the following form of multiple linear regression has been obtained:

$\mathrm{Y}=\mathrm{a}+\mathrm{b} 1 \mathrm{X} 1+\mathrm{b} 2 \mathrm{X} 2+\mathrm{b} 3 \mathrm{X} 3$

$\mathrm{Y}=33.289+0.209 \mathrm{X} 1-0,235 \mathrm{X} 2+0.671 \mathrm{X} 3$

Based on the results of the equation it can be explained that:

1. Constants (a) $=33.289$, showing the amount of employee performance, if the organizational culture, organizational commitment and motivation are zero, the the amount of employee performance is 33.289 .

2. The coefficient of organizational culture produces a calculated value of Sig. is lower than 0.05 and the t-count value 3.013. Thus hypothesis test was accepted.

3. The coefficient of organizational commitment produces the calculated value of Sig. is higher than 0.05 and the t-count value 1.378. Thus hypothesis test was not accepted.

4. The coefficient of motivation produces the calculated value of Sig. is smaller than 0.05 and the tcount value 3.467. Thus hypothesis test was accepted.

Table 7. Simultaneous Regression Test (F Test)

\begin{tabular}{llclcc}
\hline \multicolumn{1}{c}{ Model } & Sum of Square & df & Mean Square & F & Sig. \\
\hline Regression & 788.834 & 3 & 262.945 & 13.481 & 0.000 \\
\hline Residual & 1.423 .841 & 73 & 19.505 & & \\
\hline Total & 2.212 .675 & 76 & & & \\
\hline
\end{tabular}

From Table 7. above, the data exposure above is as follows:

1. The f-count value $13.481>$ f-tab. (2.73)

2. The coefficients of organizational culture, organizational commitment and motivation has a higher f-count than f-tab. and Sig. 0.000 is lower than 0.05. Therefore, it can be argued that organizational culture, organizational commitment and motivation have no significant effect on employee performance. 
Table 8. Partial Regression Test (t Test)

\begin{tabular}{|c|c|c|c|c|c|}
\hline \multirow[b]{2}{*}{ Model } & \multicolumn{2}{|c|}{$\begin{array}{l}\text { Unstandardized } \\
\text { Coefficients }\end{array}$} & \multirow{2}{*}{$\begin{array}{c}\begin{array}{l}\text { Standardized } \\
\text { Coefficients }\end{array} \\
\text { Beta } \\
\end{array}$} & \multirow[b]{2}{*}{$\mathbf{t}$} & \multirow[b]{2}{*}{ Sig. } \\
\hline & B & Std. Error & & & \\
\hline (Constant) & 33.289 & 6.569 & & 5.068 & 0.000 \\
\hline $\mathrm{X} 1$ & 0.209 & 0.069 & 0.324 & 3.013 & 0.004 \\
\hline $\mathrm{X} 2$ & -0.235 & 0.171 & -0.160 & 1.378 & 0.172 \\
\hline $\mathrm{X} 3$ & 0.671 & 0.193 & 0.444 & 3.467 & 0.001 \\
\hline
\end{tabular}

From Table 8. above, the data from the t-test results are as follows:

1. The coefficient of organizational culture produces a calculated value of Sig. is lower than 0.05 and the t-count value higher than t-tab $(3.013>1.993)$.

2. The coefficient of organizational commitment produces the calculated value of Sig. is higher than 0.05 and the $\mathrm{t}$-count value lower than $\mathrm{t}$-tab $(1.378<1.993)$.

3. The coefficient of motivation produces the calculated value of Sig. is smaller than 0.05 and the tcount value higher than t-tab $(3.467>1.993)$.

Therefore, it can be stated partially that organizational culture and motivation have significant effect while organizational commitment has no effect on employee performance.

Table 9. Coefficient of Determination Test

\begin{tabular}{|c|c|c|c|c|}
\hline Model & $\mathbf{R}$ & R Square & Adjusted R Square & $\begin{array}{l}\text { Std. Error of the } \\
\text { Estimate }\end{array}$ \\
\hline & 0.597 & 0.357 & 0.330 & 4.416 \\
\hline
\end{tabular}

The performance variable resulted in a calculation value of $35.7 \%$ contributed by organizational culture, organizational commitment and motivation, while the remaining $64.3 \%$ was contributed by other variables.

\section{Inter-Demensional Correlation}

Table 10. Inter-Dimensional Correlation

\begin{tabular}{|l|l|l|l|l|l|l|}
\hline Dimensions & $\begin{array}{l}\text { Quality } \\
\text { (Y1) }\end{array}$ & $\begin{array}{l}\text { Quantity } \\
\text { (Y2) }\end{array}$ & $\begin{array}{l}\text { Discipline } \\
\text { (Y3) }\end{array}$ & $\begin{array}{l}\text { Efectiveness } \\
\text { (Y4) }\end{array}$ & $\begin{array}{l}\text { Independence } \\
\text { (Y5) }\end{array}$ & $\begin{array}{l}\text { Commitment } \\
\text { (Y6) }\end{array}$ \\
\hline BO & & & & & & \\
\hline Inovation in decision making & 0,310 & 0,366 & 0,015 & 0,373 & 0,435 & 0,248 \\
\hline Attention to detail & 0,335 & 0,411 & 0,102 & 0,364 & 0,306 & 0,330 \\
\hline Orientation by results & 0,433 & 0,366 & 0,189 & 0,499 & 0,399 & 0,323 \\
\hline Orientation by individu & 0,269 & 0,263 & 0,011 & 0,277 & 0,289 & 0,168 \\
\hline Orientation by team & 0,230 & 0,326 & $\mathbf{0 , 0 0 8}$ & 0,244 & 0,308 & 0,193 \\
\hline Agressive & 0,502 & $\mathbf{0 , 5 4 1}$ & 0,494 & 0,563 & 0,434 & 0,427 \\
\hline Stability & 0,322 & 0,495 & 0,305 & 0,408 & 0,417 & 0,298 \\
\hline KO & & & & & & \\
\hline Emoticon based & -0.025 & 0,155 & $-0,115$ & -0.090 & 0,014 & 0,356 \\
\hline Cost based & $\mathbf{0 , 4 8 1}$ & 0,326 & 0,044 & 0,263 & 0,298 & 0,415 \\
\hline Obligation based & $-0,117$ & 0,182 & $-0,122$ & $\mathbf{0 , 0 1 1}$ & 0,084 & 0,306 \\
\hline M & & & & & \\
\hline Need for Achievement & 0,338 & 0,356 & 0,121 & 0,357 & 0,421 & 0,496 \\
\hline Need for Power & 0,244 & 0,396 & 0,216 & 0,332 & 0,291 & $\mathbf{0 , 5 3 9}$ \\
\hline Need for Affiliation & $\mathbf{0 , 0 7 1}$ & 0,477 & 0,274 & 0,254 & 0,334 & 0,413 \\
\hline
\end{tabular}


Explanation of Table 10. above are:

1. The organizational culture variable has a close relationship between the aggressiveness dimension and the quantity dimension of the performance variable, the magnitude of the value is 0.541 (close).

2. The organizational commitment variable has a close relationship between the cost-based dimension and the quality dimension of the performance variable, the magnitude of the value is 0.481 (close).

3. The motivation variable has a close relationship between the power need dimension and the commitment dimension of the performance variable 0.539 (close).

\section{Discussion}

There are results that organizational culture has an influence on employee performance and in line with previous research Endang Sri Wahyuni et al. (2016). This means that if the variable is meaningful in efforts to improve performance which is required by organizational culture and becomes an obligation for the company to from a pattern of employee character planted by the company. If a positive individual character is formed so that the output issued is optimal for his work.

There are results that organizational commitment has no effect on employee performance in line with the research of Muhammad Irfani Hendri (2019). This finding indicates that organizational commitment has little effect on performance. Substantively it can be explained that organizational commitment efforts have very little effect on employee performance, so organizations need to pay attention to organizational commitment because organizational commitment is a feeling that individuals have for their attitudes and behavior that indirectly identify themselves as part of the organization, have a close relationship in process of organizational activities and loyal in order to achieve company goals.

There are results that motivation has an influence on employee performance in line with research of Selvi Zola Fenia (2018). Substantively it can be explained that motivation is able to build an optimistic attitude regarding their duties and responsibilities towards work. The high morale possessed by employees will have an impact on optimizing their performance in achieving company targets.

\section{CONCLUSIONS and SUGGESTIONS}

Some of the conclusions obtained are:

1. Organizational culture has a significant effect on employee performance.

2. Organizational commitment has no significant effect on employee performance.

3. Motivation has a significant effect on employee performance.

4. Organizational culture, organizational commitment and motivation together have no significant effect on employee performance.

Some of the suggestions obtained are:

1. For the company's management to continuously instill the importance of an organizational culture that can make an important contribution to employee performance. Building positive noble values can create positive employee characters so that the output produced is optimal in maintaining organizational life.

2. Even though organizational commitment has little effect on employee performance, controlling both organizational culture and motivation will always be there and it is still important to be socialized to employees that they are still members of the whole organization. 
3. The managements of the company strives to continuously meet the needs of employees, especially the need for power so that employees work competently, on time and have a responsible attitude.

4. The management of the company strives to continuously improve the organization along with organizational culture and commitment, motivation and performance to achieve strive for excellence or results and achievement oriented so that the company's goals can be achieved effectively.

5. For futher researchers, they can review with an in-depth study, one way is by conducting in-dept interviews with respondents regarding the problems in this study so that the acquisition of data and information is clearer. It is hoped that the next research will be supported by a larger population and add new variables so that the research results can be closer to perfection, provide benefits and synergize with the results of this study.

\section{BIBLIOGRAPHY}

B, Uno, Hamzah. (2012). Teori Motivasi dan Pengukurannya. Jakarta: Bumi Aksara.

Dessler, G. (20150. Manajemen Sumber Daya Manusia. Jakarta: Salemba Empat.

Endang, S. W., Taufeni, T., \& Vince, R. (2016). Pengaruh Budaya Organisasi, Locus of Control, Stres Kerja Terhadap Kinerja Aparat Pemerintah Daerah dan Kepuasan Kerja sebagai Intervening Variabel (Studi Empiris Pada Pemerintah Kabupaten Bengkalis). Jurnal Manajemen Universitas Riau, 20 (02), 189-206.

Rahmat, A. \& Elmi, F. (2020). Analysis of The Effect of Electronic Document Management System, Organizational Commitment and Work System on Employee Performance PT Graha Fortuna Purnama, International Journal of Innovative Science and Research Technology, Mercu Buana University, Jakarta, Indonesia.

Robbins, Stephen P. \& Judge, Timothy A. (2013). Organizational Behavior. $15^{\text {th }}$ ed. New Jersey: Pearson Education.

Robbins, Stephen P. \& Judge, Timothy A. (2015). Perilaku Organisasi. Edisi 16. Jakarta: Salemba Empat.

Robbins, Stephen P, \& Coulter, M. (2016). Manajemen Jilid 1 dan 2, Edisi 13, Jakarta: Erlangga.

Saluy, B. A., Wajdi. F. M., \& Chaerudin. (2018). Pengaruh Kompetensi Guru, Budaya Organisasi dan Iklim Kerja Terhadap Kinerja Guru (Studi Kasus SMK Sandikta Pondok Melati Bekasi). Jurnal Ilmiah and Manajemen Bisnis, 2 (3), 26-42.

Selvi, Z. F. (2018). Pengaruh Motivasi Kerja, Pelatihan Dosen dan Komitmen Organisasi Terhadap Kinerja Dosen Pada Sekolah Tinggi X di Sumatera Barat. Jurnal Benefita, 3 (1), 77-83.

Simamora, H. (2015). Manajemen Sumber Daya Manusia. Edisi 17. Jakarta: Balai Pustaka. 
Slamet, R., S. P. Emiliana., \& Nurchayati. (2016). Peran Komitmen Organisasi Sebagai Mediasi Hubungan Kepemimpinan Transformasional dan Sistem Reward Terhadap Kinerja Karyawan. Media Ekonomi dan Manajemen, 31 (2), 144-159.

Wibowo. (2016). Budaya Organisasi: Sebuah Kebutuhan Untuk Meningkatkan Kinerja Jangka Panjang. Edisi 2. Jakarta: RajaGrafindo Persada. 